original article | UDC 631.354.2 | doi: 10.31210/visnyk2021.01.37

STUDYING THE RELIABILITY OF HYDRAULIC SYSTEM ELEMENTS OF GRAIN COMBINE HARVESTERS

\section{O. A. Burlaka* \\ O. V. Gorbenko \\ A. O. Kelemesh}

\author{
ORCID (iD) 0000-0002-2296-7234 \\ ORCID (D) 0000-0003-2473-0801 \\ ORCID (iD 0000-0001-9429-8570
}

* Corresponding author

E-mail: antonkelemesh@gmail.com

Poltava State Agrarian Academy, 1/3, Skovorody str., Poltava, 36003, Ukraine

\begin{tabular}{l||l} 
How to Cite & $\begin{array}{l}\text { Burlaka, O. A., Gorbenko, O. V., \& Kelemesh, A. O. (2021). Studying the reliability of } \\
\text { hydraulic system elements of grain combine harvesters. Bulletin of Poltava State } \\
\text { Agrarian Academy, (1), 292-301. doi: 10.31210/visnyk2021.01.37 }\end{array}$
\end{tabular}

The article presents the results of scientific research on the main reasons for failure of KN 50.16.U1 pressure valve plunger and ways to restore it. The mechanism is used in the main hydraulic systems of "Nyva-effect", "Don-680" "Don-680M"brands of grain combine harvesters, and also grain combine harvesters of "Don", "Vector" and "Acros" series. The chosen topic is relevant because in most cases, the consequence of the failure of KN 50.16.U1 is a complete failure of the main hydraulic system, or partial failure of its components with a significant operation slowdown of the of the hydraulic system cylinders. Moreover, an emergency case is the valve plunger seizing in the intermediate position. This case is usually accompanied by ruptures of high-pressure pipelines, ruptures or failure due to the formation of internal leaks of gear pumps such as NSh-32, NSh-28. Even being able to operate, but technologically incorrectly adjusted KN 50.16.U1 valve leads to accelerated wear of other elements of the combine main hydraulic system: gear pumps, sectional electrohydraulic distributors. During the study, the following methods were used: organoleptic, direct measurement of absolute linear values, mathematical methods of processing the results of experimental studies. According to the results of measuring the absolute dimensions of the diameter of the cylindrical part of KN 50.16.U1 pressure valve plunger in the zone of intensive wear, it was found that: $25 \%$ of plungers in KN 50.16.U1 pressure valves need to be restored due to mechanical wear; about $20 \%$ of plungers in KN 50.16.U1 pressure valves have traces of corrosion chemical wear; about $10 \%$ of the studied samples have traces of both mechanical and corrosion wear. Thus, the repair of most of the investigated valves - about 55\%, requires not only the replacement of rubber and plastic seals and rings, but also galvanic restoration of the working surfaces of KN 50.16.U1 valve plunger with subsequent grinding and polishing of the working cylindrical surface to nominal size.

Key words: hydraulic system, combine harvester, wear, valve plunger, restoration, technical service.

\title{
ДОСЛІДЖЕННЯ НАДІЙНОСТІ ЕЛЕМЕНТІВ ГІДРОСИСТЕМИ ЗЕРНОЗБИРАЛЬНИХ КОМБАЙНІВ
}

\section{О. А. Бурлака, О. В. Горбенко, А. О. Келемеш}

Полтавська державна аграрна академія, м. Полтава, Україна

У статті викладені результати наукових досліджень основних причин відмови в роботі та обтрунтовані шляхи відновлення плунжера клапана напірного КН 50.16 У1, що використовується в основних гідросистемах зернозбиральних комбайнів марок «Нива-ефект», серії «Дон», серії «Вектор», 


\section{TEХНIЧНI НАУКИ}

серії «Акрос», кормозбиральних комбайнів марок "Дон-680», "Дон-680М». Обрана тема актуальна, оскільки дуже часто наслідком виходу з ладу КН 50.16 У 1 є повна відмова основної гідросистеми або часткова відмова ї̈ складових частин зі значним уповільненням роботи ииліндрів гідросистеми. До того ж аварійним випадком є заклинювання плунжера клапана у проміжному положенні, що супроводжується, як правило, розривами трубопроводів високого тиску, виходом з ладу через утворення внутрішніх протічок шестеренних насосів типу НШ-32, НШ-28. Навіть прачездатний, але технологічно неправильно відрегульований клапан КН 50.16 У1 призводить до прискореного зносу інших елементів основної гідросистеми комбайна: шестеренних насосів, секиійних електрогідророзподільників. При проведенні дослідження були застосовані методи органолептичний, безпосереднього вимірювання абсолютних лінійних величин, математичні методи обробки результатів експериментальних досліджень. За результатами вимірювання абсолютних розмірів діаметру циліндричної частини плунжера клапана напірного КН 50.16.У1 у зоні інтенсивного зносу було виявлено: 25 \% плунжерів у напірних клапанах КН 50.16.У1 потребують відновлення через механічний знос; близько $20 \%$ плунжерів у напірних клапанах КН 50.16.У1 мають сліди корозійного хімічного зносу; близько $10 \%$ із досліджуваних зразків мають сліди як механічного, так і корозійного зносу. Отже, ремонт більшості досліджуваних клапанів - близько $55 \%$, потребує не тільки заміни гумових та пластикових ущільнювачів та кілечь, але й гальванічного відновлення робочих поверхонь плунжера клапана КН 50.16.У1 подальшим шліфуванням та поліруванням робочої ииліндричної поверхні до номінального розміру.

Ключові слова: гідросистема, комбайн, знос, плунжер клапана, відновлення, технічний сервіс.

\section{Вступ}

Сучасний зернозбиральний комбайн - це складна технологічна система, якість та надійність роботи якої впливає на підсумковий результат виробничих технологій вирощування та збирання зернових, зернобобових та технічних культур у рослинництві.

Комплекс наукових досліджень, що присвячені зернозбиральним комбайнам, містить праці таких відомих українських вчених: Погорілого Л. В., Сакуна В. А., Шейченка В. О., Погорільція О. М., Головчука А. Ф, Демко А. А., Зенко М. Д., Ліника М. К., Нєдовєсова В. І. та ін. [8, 16, 26, 27, 28, 7].

Питання якості сепарації хлібної маси молотарками зернозбиральних комбайнів досліджено в наукових міжнародних публікаціях [21, 22, 23, 24, 26, 27, 28].

Обговорення результатів досліджень щодо впливу системи технічного сервісу на якість роботи зернозбиральних комбайнів викладено у працях $[1,2,3,4,5,6,8,9]$.

Наукові засади формування надійності підсистем зернозбиральних комбайнів та оцінка їхньої ефективності описана в публікаціях $[11,12,13,14,15]$.

Питання взаємозв'язків технічного сервісу, методик та методологій відновлення деталей зернозбиральних комбайнів та визначення інтегрованих показників ефективності роботи зернозбиральних комбайнів наведено у працях $[16,17,18,19,29,30]$.

Але, зважаючи на досить всеосяжний комплекс результатів наукових досліджень 3 підвищення надійності роботи зернозбиральних комбайнів, межі наукового пошуку не існує, а деякі питання розкриті недостатньо. На нашу думку, нових аспектів можуть набути дослідження елементів гідросистем комбайнів марок «Нива-ефект», «Дон-680», «Дон-680М» серій: «Дон», «Вектор», «Акрос», що досить широко використовують аграрні підприємства України.

Ця наукова публікація присвячена дослідженню надійності роботи та удосконаленню технологій відновлення ключового елементу основної гідросистеми зернозбиральних комбайнів марок «Ниваефект», кормозбиральних комбайнів марок «Дон-680», «Дон-680М»; зернозбиральних комбайнів сеpiї «Дон», серії «Вектор», серії «Акрос» - клапана напірного КН 50.16 У1 (КН50-12,6\108.00.000). Стисло відмітимо, що основними функціями такого гідравлічного вузла є створення холостого режиму роботи основної гідросистеми; режиму роботи під тиском (як правило $12,5 \mathrm{MПа} \mathrm{або} \mathrm{16,5МПа)} \mathrm{та}$ запобігання перевантаженню гідросистеми - скидання надлишкового гідравлічного масла, якщо тиск перевищує номінальний розрахунковий (12,5МПа або $16,5 \mathrm{MПа).}$

Ми не будемо детально описувати принцип роботи та будову напірного гідроклапана, а саме зупинимося на особливостях його діагностування, використання, технічного обслуговування та ремонту деяких основних елементів. Тобто викладена в подальшому інформація, на нашу думку, буде актуальна не тільки 3 наукової, але і з практичної точки зору, зокрема аграрним підприємствам різних організаційно-правових форм господарювання, де використовують зернозбиральні комбайни таких моделей. 
Вибір об’єкту досліджень (клапана напірного КН 50.16 У1) обгрунтовано такими факторами:

1. Аварійна ситуація основної гідросистеми зернозбирального комбайна може бути причиною виникнення нещасних випадків при роботі на комбайні.

2. Відмова у його роботі може бути спричинена недоліками конструкції клапана, фізичним зносом його деталей та порушенням правил експлуатації основної гідросистеми зернозбирального комбайна.

3. Переважно наслідком виходу з ладу КН 50.16 У1 є повна відмова основної гідросистеми або часткова відмова іï складових частин зі значним уповільненням роботи циліндрів відносно невеликого об'єму - циліндри вивантажувального шнеку, молотарки, варіаторів.

4. Більш неприємним та небезпечним аварійним випадком є заклинювання плунжера клапана 7 (рис. 1) у проміжному положенні, коли останній своїм корпусом повністю перекриває зливну магістраль поз. 4 (рис. 1). Такий випадок супроводжується, як правило, розривами трубопроводів високого тиску, розривами, або виходом з ладу через утворення внутрішніх протічок шестеренних насосів типу НШ-32, НШ-28. Насос НШ-28 перебуває в тандемі з насосами НШ-10. Заміна такого тандема на новий або його ремонт досить вартісний.

5. Навіть працездатний, але технологічно неправильно відрегульований клапан КН 50.16 У1 призводить до прискореного зносу інших елементів основної гідросистеми комбайна: шестеренних насосів, секційних електрогідророзподільників. У цьому випадку більш типовою помилкою $є$ завищення тиску спрацювання запобіжної частини клапана КН 50.16 У1. (більше 12,5МПа у більш ранніх модифікацій або більше 16,5 МПа - ДОН-1500Б та новіші моделі).

6. Вартість нового оригінального клапану КН 50.16 У1. перевищує 3000 грн та він не завжди підходить на конкретну марку комбайна.

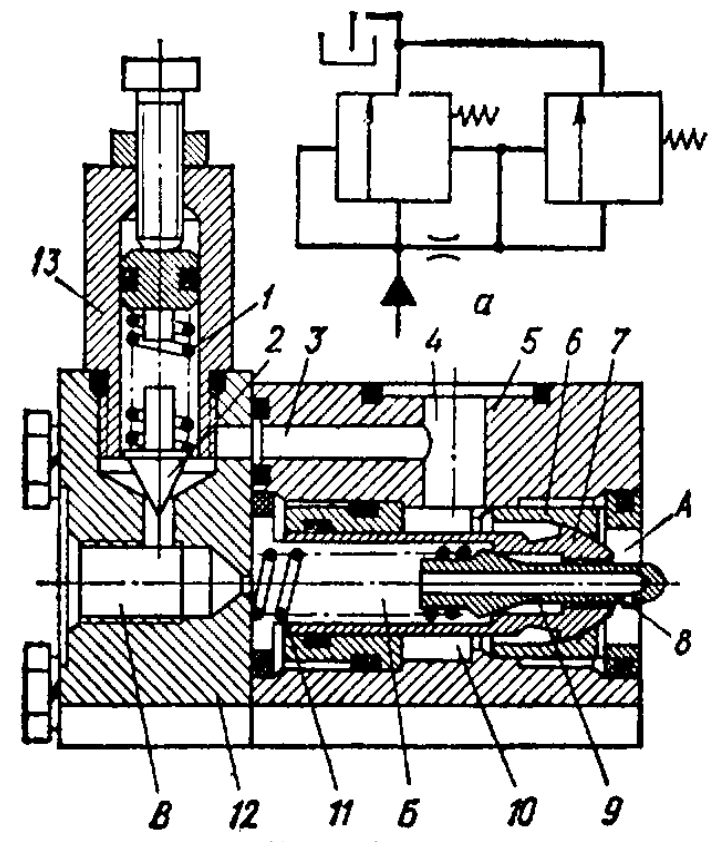

Рис. 1. Конструктивна та гідравлічна схеми клапана КН 50.16 У1.

Позначки: а - гідравлічна схема; в - конструктивна схема: 1 - пружина запобіжної секції, 2 - голка; 3 - дренажний канал; 4 - зливна магістраль; 5 - корпус напірно-переливної секції; 6 - сідло; 7 - плунжер; 8 - дросельний отвір потоку управління; 9 - конічна вставка плунжера; 10 - зливні отвори; пру-

жина плунжера; 12 - корпус переливної секції; 13 - корпус запобіжної секції. Джерело: [30].

7. На ринку України існує пропозиція неоригінальних клапанів КН 50.16 У1 (КН5012,6\108.00.000) (рис. 2 поз. Б), які порівняно з оригінальними (рис. 2, поз. В, Г ) мають набагато більшу вірогідність аварійних станів та відмов або $є$ взагалі непрацездатними.

Вищенаведені пункти, на нашу думку, є достатнім підгрунтям для доведення доцільності відновлення такого гідравлічного компонента, як КН 50.16 У1.

На основі викладеного метою цієї статті є дослідження ступеня зносу основних деталей та пошук оптимальних способів відновлення клапана напірного КН 50.16 У1. 

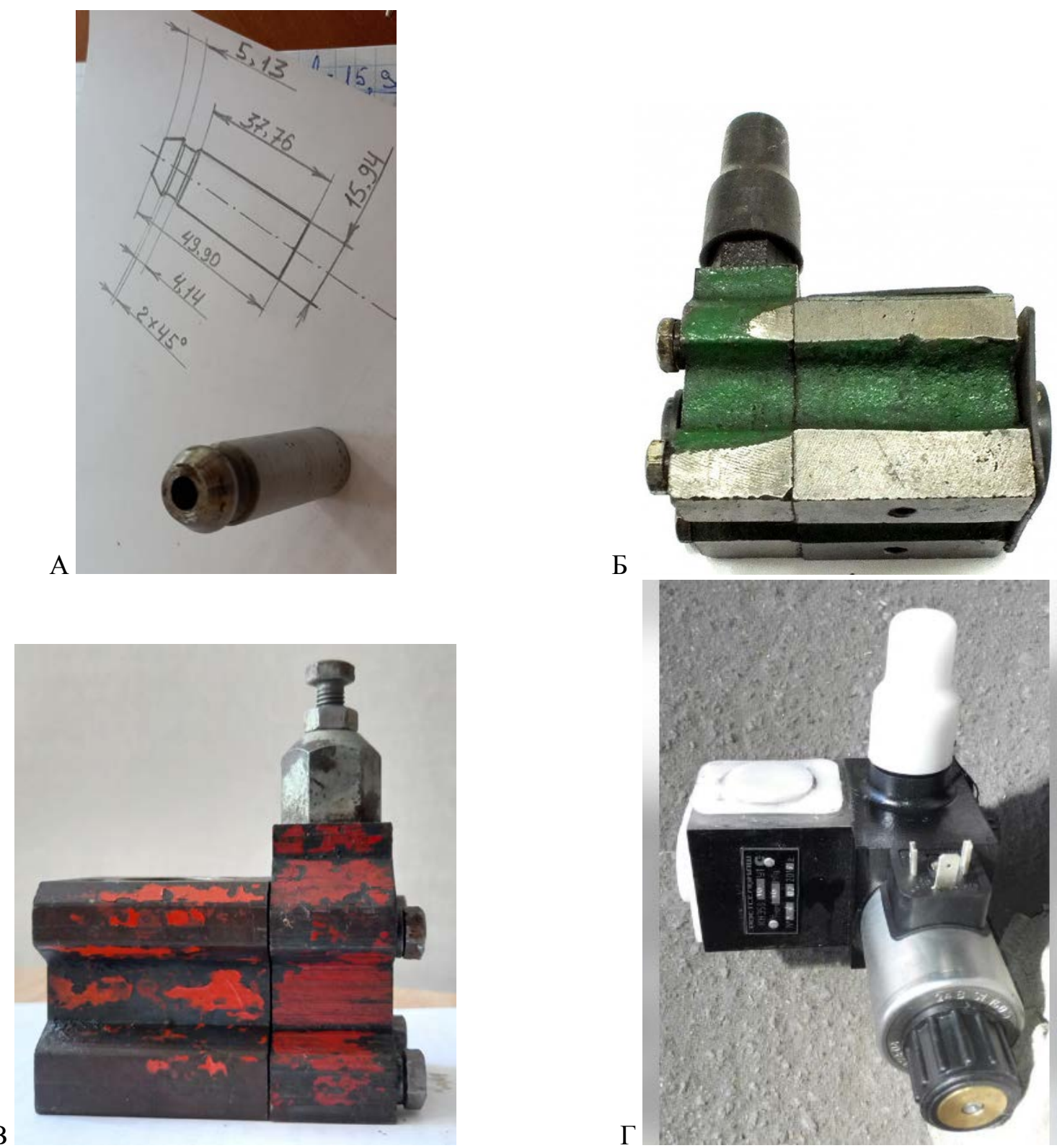

Рис. 2. Об’єкт дослідження - клапан напірний КН 50.16 У1 (КН50-12,61108.00.000

Позначки: А - схема та загальний вигляд плунжера клапана КН 50.16 У1;

Б - Клапан напірний КН 50.16 У1 (неоригінальний);

В - Клапан напірний КН 50.16 УІ (оригінальний - ранні моделі серія «Дон»);

Г-Клапан напірний КН 50.16 УІ (оригінал - більш пізні моделі, інтегрований з клапаном РПУ серія«Акрос»)

Для досягнення поставленої мети необхідно розв’язати такі завдання дослідження:

1. На основі багаторічного досвіду використання зернозбиральних комбайнів та науково-технічної співпраці з аграрними підприємствами відібрати зразки плунжерів клапанів КН 50.16 У1, що відмовили в роботі та потребували ремонту.

2. Виміряти та дослідити абсолютні розміри плунжера клапана в зоні підвищеного зносу та визначити основні тенденції прискореного зносу плунжерів.

3. Надати науково обгрунтовані рекомендації з підвищення рівня технічної надійності клапана КН 50.16 У1 та зі способів відновлення його складових частин. 
Матеріали і методи досліджень

При проведенні наукового дослідження в цій роботі були застосовані органолептичні методи, методи безпосереднього вимірювання абсолютних лінійних величин, математичні методи обробки результатів експериментальних досліджень.

Дослідження проводили на понад, ніж 20 зразків плунжерів клапана КН 50.16 У1. (рис. 3).

Зоною вимірювання прийнято місця максимального зносу у трьох площинах поз. 1, 2, 3 (рис. 4). Знос у кожній площині вимірювався у двох взаємно перпендикулярних напрямках.

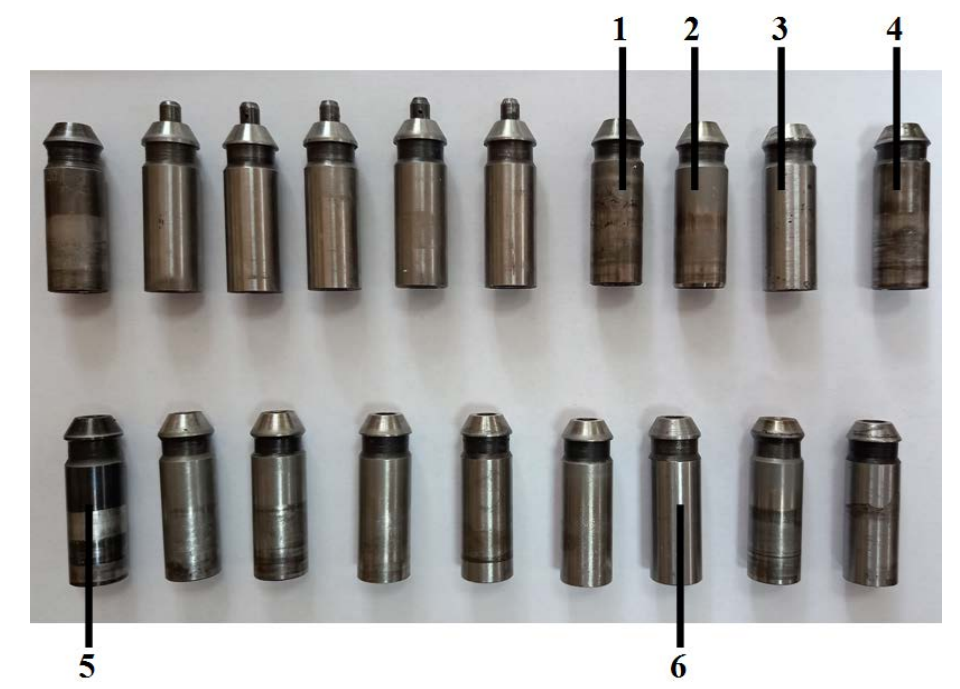

Рис. 3. Зразки плунжерів для досліджень

Позначки: 1 - плунжер з явно вираженими слідами механічного та корозійного зносу; 2 - плунжер 3 явно вираженими слідами механічного зносу; 3 - плунжер з неякісно виготовленою робочою поверхнею; 4 - плунжер з явно вираженими слідами механічного, корозійного зносу та термічного перегріву гідросистеми; 5 - плунжер з явно вираженими слідами механічного зносу та термічного перегріву гідросистеми; 6 - плунжер без явних слідів зносу.

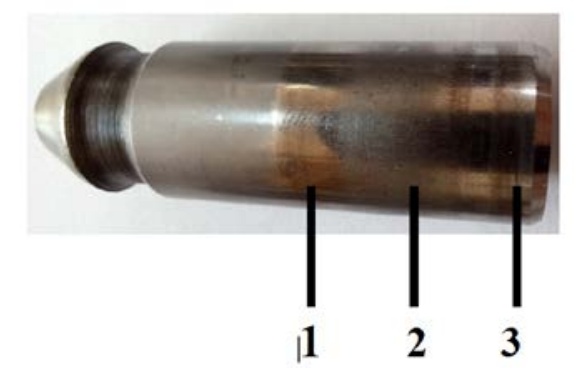

Рис. 4. Плунжер клапана КН 50.16 У1 з прийнятими для вимірювання поясами 1,2,3 в зоні максимального зносу

Для отримання більш точних та достовірних даних вимірювання абсолютних розмірів плунжера клапана КН 50.16 У1 у зоні підвищеного зносу ми використали електронний мікрометр типу МК та оптиметр (рис. 5) 


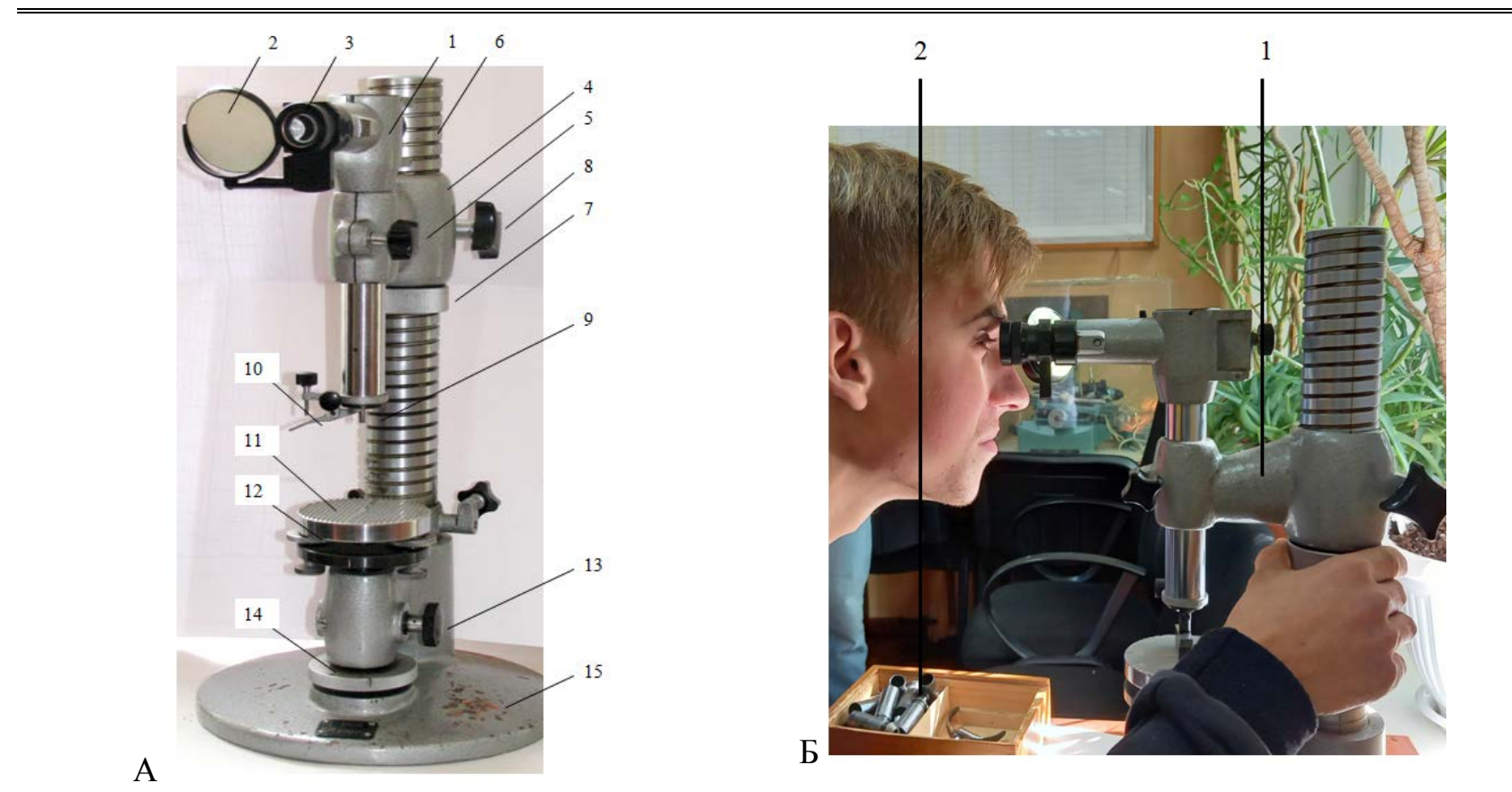

Рис. 5. Обладнання для проведення досліджень

Позначки: А - загальний вигляд вертикального оптиметра: 1 - трубка, або авто-колімаційна трубка 3 освітлюваним дзеркалом 2 і окуляром $3 ; 4$ - кронштейн, 5 - гвинт для закріплення трубки у кронштейні; 6 - колонка, 7 - гайка, яка використовується для грубої установки кронштейна й одночасно $\epsilon$ його опорою; 8 - стопор кронштейна, 9 - вимірювальний наконечник, 10 - відводка (аретир) вимірювального наконечника, 11 - предметний столик, 12 - регулювальні гвинти столика, 13 - стопор столика; 15 - основа приладу. Г - процес вимірювання дослідних зразків.

Б - вимірювання дослідного зразка оптиметром: 1 - оптиметр, 2 - дослідні зразки.

При вимірюванні оптиметром повинен бути забезпечений точковий або лінійний контакт вимірювального наконечника 3 вимірюваним об’єктом. Це досягається використанням відповідних наконечників. Для циліндричних деталей діаметром понад 10 мм використовуються сферичні наконечники.

Для вимірювання діаметрів плунжерів клапана оптиметр потрібно налаштувати на номінальний розмір плунжера за допомогою плоскопаралельних кінцевих мір. Для цього використовуються плитки номінального розміру. Далі підводиться відповідний наконечник до дотику з поверхнею плиток і установлюється шкала оптиметра на нуль. Потім відводкою відвести наконечник, а замість плиток встановити плунжер. Притиснувши до столика, фіксують положення шкали оптиметра.

Дійсний розмір плунжера підраховують за формулою [29, 30]:

$$
d_{\partial}=N \pm \Delta \text {, }
$$

де $N$ - розмір блоку плиток, рівний номінальному розміру деталей;

$\Delta$ - відхилення стрілки від нуля в поділках шкали.

\section{Результати досліджень та їх обговорення}

На основі практичного досвіду використання зернозбиральних та кормозбиральних комбайнів в аграрних підприємствах, можна визначити такі основні причини виходу з ладу клапана напірного КН $50.16 \mathrm{Y} 1$ :

1) наявність сторонніх домішок та часток у маслі основної гідравлічної системи комбайна;

2) знос, руйнування та старіння гумових та полімерних ущільнювачів;

3) втрата жорсткості зворотної пружини (поз. 11, рис. 1);

4) знос поверхні плунжера напірно-переливної частини (поз. 7, рис. 1);

5) послаблення різьбового з'єднання в зоні запобіжної частини клапана (поз. 13, рис. 1);

6) знос конічних посадок: плунжер - сідло (зона А, рис. 1);

7) знос конічних посадок: голка - сідло (поз. 2, рис. 1)

Не викликає сумніву, що при виконанні якісних ремонтно-обслуговуючих робіт, всі гумові та по- 
лімерні ущільнювачі клапана підлягають заміні.

Наше дослідження, як вище згадано, зосереджено на оцінці причин зносу, технічного стану циліндричної поверхні плунжера клапана КН 50.16 У1 та пошуку шляхів його науково обгрунтованого відновлення.

3 технічних вимог до виготовлення деталей гідроапаратури, що працює робочими поверхнями 3 ущільнювальними гумовими елементами - прийнятий 9 квалітет. Тому відхилення дійсних розмірів діаметру плунжера від його номінального розрахункового значення матимуть розміри: максимально допустимий діаметр = 15,984 мм; мінімально допустимий діаметр - 15,941 мм;

Результати вимірювання абсолютних розмірів діаметру циліндричної частини плунжера клапана напірного КН 50.16.У1 в зоні інтенсивного зносу подано в табл. 1.

1. Результати вимірювання абсолютних розмірів діаметру в зоні інтенсивного зносу плунжера клапана напірного КН 50.16 У1

\begin{tabular}{|c|c|c|c|c|c|c|}
\hline \multirow{3}{*}{$\begin{array}{c}\text { Номер зраз- } \\
\text { ка }\end{array}$} & \multicolumn{2}{|c|}{1 пояс } & \multicolumn{2}{|c|}{2 пояс } & \multicolumn{2}{|c|}{3 пояс } \\
\hline & \multicolumn{6}{|c|}{ Перерізи вимірювання } \\
\hline & A-A & Б-Б & A-A & Б-Б & A-A & Б-Б \\
\hline 1 & 15,965 & 15,962 & 15,972 & 15,967 & 15,977 & 15,970 \\
\hline 2 & 15,971 & 15,969 & 15,973 & 15,972 & 15,978 & 15,967 \\
\hline 3 & 15,967 & 15,965 & 15,974 & 15,973 & 15,969 & 15,976 \\
\hline 4 & 15,672 & 15,962 & 15,966 & 15,964 & 15,963 & 15,967 \\
\hline 5 & 15,927 & 15,922 & 15,927 & 15,928 & 15,923 & 15,928 \\
\hline 6 & 15,961 & 15,955 & 15,958 & 15,959 & 15,960 & 15,956 \\
\hline 7 & 15,951 & 15,954 & 15,955 & 15,955 & 15,955 & 15,955 \\
\hline 8 & 15,960 & 15,964 & 15,965 & 15,964 & 15,964 & 15,975 \\
\hline 9 & 15,963 & 15,968 & 15,973 & 15,971 & 15,968 & 15,968 \\
\hline 10 & 15,963 & 15,967 & 15,964 & 15,968 & 15,966 & 15,967 \\
\hline 11 & 15,959 & 15,961 & 15,977 & 15,969 & 15,960 & 15,958 \\
\hline 12 & 15,940 & 15,952 & 15,955 & 15,954 & 15,960 & 15,956 \\
\hline 13 & 15,960 & 15,956 & 15,968 & 15,963 & 15,970 & 15,970 \\
\hline 14 & 15,951 & 15,940 & 15,952 & 15,950 & 15,947 & 15,947 \\
\hline 15 & 15,936 & 15,945 & 15,949 & 15,950 & 15,948 & 15,933 \\
\hline 16 & 15,937 & 15,945 & 15,950 & 15,953 & 15,951 & 15,949 \\
\hline 17 & 15,967 & 15,967 & 15,972 & 15,967 & 15,967 & 15,974 \\
\hline 18 & 15,970 & 15,964 & 15,968 & 15,969 & 15,970 & 15,969 \\
\hline 19 & 15,964 & 15,962 & 15,963 & 15,961 & 15,960 & 15,965 \\
\hline 20 & 15,941 & 15,951 & 15,955 & 15,964 & 15,543 & 15,967 \\
\hline
\end{tabular}

3 таблиці 1 видно, що зразки № 5, 12, 14, 15 та 16 мають механічний знос, що виходить за допуски на виготовлення плунжера. Такі зразки потребують відновлення. Зважаючи на конструктивні особливості клапана та характер його роботи, на нашу думку, найбільш оптимальним способом відновлення $\epsilon$ гальванічне нарощування металу на зношені поверхні з подальшим шліфуванням та поліруванням до номінального розміру і відповідної шорсткості.

Вагомим є те, що майже 25 \% плунжерів у напірних клапанах КН 50.16.У1 потребують відновлення через механічний знос.

За результатами органолептичних досліджень близько 20 \% плунжерів у напірних клапанах КН 50.16.У1 мають сліди корозійного хімічного зносу. На нашу думку, такі явища стали наслідком використання гідравлічного масла 3 кислим середовищем (як правило це відпрацьоване масло двигуна) або масла $з$ перевищеною концентрацією сірки. Остання в поєднанні з вологою і високою температурою дає кислу реакцію через утворення компонентів сірчаної кислоти.

Близько $10 \%$ д досліджуваних зразків мають сліди як механічного, так і корозійного зносу, тому також потребують гальванічного відновлення.

Тобто, як видно з результатів проведених досліджень, якісний ремонт вагомої частини клапанів КН 50.16.У1 - близько 55 \%, потребує не тільки заміни гумових та пластикових ущільнювачів та кілець, але й гальванічного відновлення робочих поверхонь плунжера клапана КН 50.16.У1. 


\section{TЕХНІЧНI НАУКИ}

Також треба відмітити, що на термін технічної справності клапана напірного КН 50.16.У1 впливає марка масла, що використовується в основній гідравлічній системі: М-10Г 2 , М-10B 2 ГОСТ 8581-78 (літнє - при максимально допустимій температурі масла $+80^{\circ} \mathrm{C}$ ), М-8 $\Gamma_{2}, \mathrm{M}-8 \mathrm{~B}_{2}$ ГОСТ 8581-78, М-8А ГОСТ 10540-78 (зимове - при максимально допустимій температурі масла $+65^{\circ} \mathrm{C}$ ), або в системах 3 інтегрованими баками МГЕ-46В (МГ-30У) ТУ 38.001347-83. Якщо на комбайнах встановлена гідростатична трансмісія закордонного виробництва, то масло згідно з інструкцією 3 використання такої трансмісії.

Останнім часом необхідно звертати увагу і на якість фільтруючих елементів гідросистем комбайнів, особливо в машинах з інтегрованими баками.

\section{Висновки}

1. Одним з основних та функціонально важливих елементів основних гідросистем зернозбиральних та кормозбиральних комбайнів марок «Нива-ефект», «Дон-680», «Дон-680М» серій: «Дон», «Вектор», «Акрос», що досить широко використовують аграрні підприємства України, слід вважати клапан напірний КН 50.16 У1, тому, що відхилення в його роботі (відмова) може призвести до суттєвих матеріальних втрат та нещасних випадків, зокрема і пожеж під час проведення збиральних робіт.

2. Заклинювання плунжера клапана КН 50.16 У1 в середньому положенні супроводжується, як правило, розривами трубопроводів високого тиску, розривами, або виходом з ладу через утворення внутрішніх протічок шестеренних насосів типу НШ-32, НШ-28.

3. На основі багаторічного досвіду використання зернозбиральних комбайнів та науково-технічної співпраці з аграрними підприємствами ми відібрали понад 20 зразків плунжерів клапанів КН 50.16 У1, що відмовили в роботі та потребували ремонту.

4. За результатами вимірювання абсолютних розмірів діаметру циліндричної частини плунжера клапана напірного КН 50.16.У1 в зоні інтенсивного зносу за допомогою вертикального оптиметра було виявлено: майже 25 \% плунжерів у напірних клапанах КН 50.16.У1 потребують відновлення через механічний знос; близько 20 \% плунжерів у напірних клапанах КН 50.16.У1 мають сліди корозійного хімічного зносу; близько $10 \%$ досліджуваних зразків мають сліди як механічного, так і корозійного зносу. Отже, якісний ремонт вагомої частини досліджуваних клапанів - близько 55 \%, потребує не тільки заміни гумових та пластикових ущільнювачів і кілець, але й гальванічного відновлення робочих поверхонь плунжера клапана КН 50.16.У1.

5. Встановлено, що на термін технічної справності клапана напірного КН 50.16.У1 впливає марка масла, що використовується в основній гідравлічній системі: М-10 $\Gamma_{2}, \mathrm{M}-10 \mathrm{~B}_{2}$ ГОСТ 8581-78 (літнє при максимально допустимій температурі масла $\left.+80^{\circ} \mathrm{C}\right)$, М-8 $\Gamma_{2}, \mathrm{M}-8 \mathrm{~B}_{2}$ ГОСТ 8581-78, М-8А ГОСТ 10540-78 (зимове - при максимально допустимій температурі масла $+65^{\circ} \mathrm{C}$ ), або в системах з інтегрованими баками МГЕ-46В (МГ-30У) ТУ 38.001347-83. Якщо на комбайнах встановлена гідростатична трансмісія закордонного виробництва, то масло згідно з інструкцією з використання такої трансмісії.

Перспективи подальших досліджень. Наведені в цій роботі дослідження базувалися на зниженні надійності роботи клапана напірного через механічний знос поверхонь деталей. Проте викликає зацікавлення продовження досліджень 3 метою пошуку впливу шорсткості поверхні деталі на ресурс та експлуатаційні показники роботи елементів гідросистеми зернозбиральних комбайнів.

\section{References}

1. Boyko, A., \& Dumenko, K. (2011). Vplyv efektyvnosti sfery tekhnichnoho obsluhovuvannia na vstanovlennia funktsii hotovnosti ta vidnovlennia zernozbyralnoi tekhniky. Tekhnika i Tekhnolohiyi APK, 1, 11-14 [In Ukrainian].

2. Bondarenko, O., \& Dumenko, K. (2011). Vykorystannia par tertia vuhletsevykh kompozytsiinykh materialiv $\mathrm{v}$ ekstremalnykh umovakh roboty zernozbyralnoi tekhniky. Visnyk Ahrarnoi Nauky Prychornomoria, 3 (60), 165-170 [In Ukrainian].

3. Bondar, M., Zavoloka, A., \& Svyrydenko, N. (2010). Povyshenye pozharobezopasnosty ekspluatatsyy pernouborochnoho kombayna: kontseptsyya y puty ee realyzatsyy. Tekhnika i Tekhnolohiyi APK, 8, 12-16 [In Russian].

4. Brovarets, O. O. (2014). Rehul'ovana vysota zrizu zernozbyral'nykh kombayniv - zasib pidvyshchennya efektyvnosti roboty zernozbyral'nykh kombayniv. Khranenye y Pererabotka Zerna, 3, 16-19 [In Ukrainian]. 


\section{TEХНIЧНI НАУКИ}

5. Vasyl'chenko, V., \& Ruzhylo, Z. (2012). Pidhotovka zbyral'noyi tekhniky do zymivli. Ahrarna Tekhnika ta Obladnannya, 4, 78-80 [In Ukrainian].

6. Vasyl'chenko, V. (2013) Pidhotovka kombayna do zhnyv. Shcho potribno zrobyty, aby minimizuvaty vtraty. Ahronom, 2, 202-205. [In Ukrainian].

7. Burlaka, O. A., \& Yakhin, S. V. (2018). Pidvyshchennya efektyvnosti roboty skrebkovykh elevatoriv z vidtsentrovym typom rozvantazhennya. Visnyk Poltavskoyi Derzhavnoyi Ahrarnoyi Akademiyi, 4, 195-200. doi. 10.31210/visnyk2018.04.31 [In Ukrainian].

8. Holovchuk, A. F., Marchenko, V. I., \& Orlov, V.F (2004). Ekspluatatsiya ta remont sil's'kohospodars'koyi tekhniky: pidruch. u 3 kn. Kombayny zernozbyral'ni. - Kyiv: Hramota [In Ukrainian].

9. Demko, O. A., Demko, A. A., \& Nadtochiy, O. V. (2014). Zakonomirnosti vplyvu tryvalosti ekspluatatsiyi zernozbyral'nykh kombayniv na yikh tekhnichnyy stan. Visnyk Kharkivs'koho Natsional'noho Tekhnichnoho Universytetu Sil's'koho Hospodarstva imeni Petra Vasylenka, 145, 161-167 [In Ukrainian].

10. Dumenko, K. M. (2011). Intehrovanyy pokaznyk efektyvnosti roboty zernozbyral'nykh kombayniv. Visnyk Ahrarnoyi Nauky Prychornomor'ya, 4 (61(1)), 220-224 [In Ukrainian].

11. Dumenko, K. M., \& Bondarenko, O. V. (2011). Naukovi zasady formuvannya nadiynosti pidsystem zernozbyral'nykh kombayniv Naukovyy Visnyk Luhans'koho Natsional'noho Ahrarnoho Universytetu, 9, 412-419 [In Ukrainian].

12. Dumenko, K. M. (2012). Statystychnyy analiz dynamiky rozpodilu vidmov pidsystem kombayniv. Naukovyy Visnyk Luhans'koho Natsional'noho Ahrarnoho Universytetu, 35, 113-118 [In Ukrainian].

13. Dumenko, K. M., Komisarova, L. O., \& Shevchenko, K. S. (2014). Vidnovlennya pratsezdatnoho stanu vitchyznyanykh zernozbyral'nykh kombayniv. Visnyk Kharkivs'koho Natsional'noho Tekhnichnoho Universytetu Sil's'koho Hospodarstva imeni Petra Vasylenka, 145, 21-27 [In Ukrainian].

14. Dumenko, K. M., Boyko, A. I., \& Bondarenko, O. V. (2012). Funktsiyi vidnovlennya pidsystem zernozbyral'nykh kombayniv pry riznykh rivnyakh potentsialu bazy tekhnichnoho obsluhovuvannya. Pratsi Tavriys'koho Derzhavnoho Ahrotekhnolohichnoho Universytetu, 12 (3), 42-52 [In Ukrainian].

15. Karabynesh, S., Veznyuk, V., \& Demchenko, A. (2014). Servysom po barabanu. Remont i profylaktyka molotyl'noho uzla zernouborochnoho kombayna. Zerno, 5, 156-161 [In Russian].

16. Kravchuk, V., Zan'ko, M., \& Lysak, O. (2016). Ekspluatatsiyna otsinka kombayna MF-7370PL "BETA" kompaniyi MASSEY FERGUSON na zbyrannya yachmenyu. Tekhnika i Tekhnolohiyi APK, 4, 10-17 [In Ukrainian].

17. Kukhtov, V. H., Znaydyuk, V. H., \& Pohorilyy, V. V. (2014). Do pytannya normuvannya rivnya nadiynosti novykh zernozbyral'nykh kombayniv vitchyznyanoho vyrobnytstva. Visnyk Kharkivs'koho Natsional'noho Tekhnichnoho Universytetu Sil's'koho Hospodarstva imeni Petra Vasylenka, 151, 5-12 [In Ukrainian].

18. Lytvynyuk, L. (2015). Deyaki osoblyvosti pidvyshchennya produktyvnosti zernozbyral'noho kombayna i pokrashchennya rodyuchosti hruntu. Tekhnika i Tekhnolohiyi APK, 10, 25-27 [In Ukrainian].

19. Sydorchuk, L. L. (2013). Systemnyy analiz pidprohram vykorystannya ta tekhnichnoho servisu zernozbyral'nykh kombayniv. Mekhanizatsiya i Elektryfikatsiya Sil's'koho Hospodarstva, 97 (2), 404-412 [In Ukrainian].

20. Smashnyuk, O. V. (2010). Zakonomirnosti vidmov zernozbyral'nykh kombayniv v umovakh ekspluatatsiyi. Mekhanizatsiya ta Elektryfikatsiya Sil's'koho Hospodarstva, 94, 431-437 [In Ukrainian].

21. Choi, M., Lee, K., Jang, B., Kim, Y., Chung, S., \& Lee, J. (2018) Grain flow rate sensing for a 55 kW full-feed type multi-purpose combine. International Journal of Agricultural and Biological Engineering, 11 (5), 206-210. doi: 10.25165/j.ijabe.20181105.2686

22. Fiscus, D. E., Foster, G. H., \& Raufman, H. H. (1971). Physical Damage of Grain Caused by Various Handling Techniques. Transactions of the ASAE, 14 (3), 480-485. doi: 10.13031/2013.38319

23. Menezes, P. C. de, Silva, R. P. da, Carneiro, F. M., Girio, L. A. da S., Oliveira, M. F. de, \& Voltarelli, M. A. (2018). Can combine headers and travel speeds affect the quality of soybean harvesting operations? Revista Brasileira de Engenharia Agrícola e Ambiental, 22(10), 732-738. doi: 10.1590/18071929/agriambi.v22n10p732-738

24. Shahbazi, F., Valizadeh, S., \& Dowlatshah, A. (2012). Mechanical damage to wheat and triticale seeds related to moisture content and impact energy, Agricultural Engineering International : CIGR Journal, 14 (4), 150-155.

25. Sheichenko, V., Kuzmych, A., Shevchuk, M., Shevchuk, V., \& Belovod, O. (2019). Research of 
quality indicators of wheat seeds separated by prethreshing device, INMATEH - Agricultural Engineering, 57 (1), 157-164.

26. Shpokas, L., Adamchuk, V., Bulgakov, V., \& Nozdrovicky, L. (2016). The experimental research of combine harvesters, Research in Agricultural Engineering, 62, 106-112. doi:10.17221/16/2015-RAE

27. Zielinski, A., \& Mos, M. (2009). Effects of seed moisture and the rotary speed of a drum on the germination and vigour of naked and husked oat cultivars, Cereal Research Communications, 37 (2), 277286. doi: 10.1556/crc.37.2009.2.16

28. Kelemesh, A., \& Gorbenko, O. (2015). Research of kinematic and agricultural parameters of working tools when processing the cylinder liners. Mechanization in Agriculture \& Conserving of the resources, 61 (12), 32-33.

29. Gorbenko, O., \& Kelemesh, A. (2015) Justification of choosing recovery method for cylinder liners of autotractor engines. Proceedings of the IInd International Scientific and Practical Conference "Topical Problems of Modern Science and Possible Solutions”, 24-25 Sept. 2015. 2 (2), 9-11 Dubai: UAE.

30. Vasylenko, V. S., Hramakov, N. V., Taran, I. H., \& Shchekoldin, H. A. (2000). Kombayni zernoubrochnye samokhodnye «DON-1500B» $i$ «DON-1200B». Instkruktsyya po ekspluatatsiyi $i$ tekhnicheskomu obsluhovunya. OAO «Rostsel'mash» [In Russian].

Бібліографічний опис для цитування:

Стаття надійшла до редакції 30.09.2020 р.

Бурлака О.А., Горбенко О. В., Келемеш А. О. Дослідження надійності елементів гідросистеми зернозбиральних комбайнів. Вісник ПДАА. 2021. № 1. С. 292-301.

() Бурлака Олексій Анатолійович, Горбенко Олександр Вікторович, Келемеш Антон Олександрович, 2020 